\title{
Identification and Classification of Libyan Rosmarinus Officinalis Essential Oil Components by GC-MS and Predication of Its Antioxidant Activity
}

\author{
Wessal Hassan El-Ageeli ${ }^{*}$, Bubaker M.B Hamed Al-Mansori ${ }^{1}$, Seham Hamad Moham- \\ med Alsagheer ${ }^{2}$, Faheem A. F. Ben-Khayal ${ }^{1}$ \\ ${ }^{1}$ Department of Food Science and Technology, Faculty of Agriculture, Omar Al-Mukhtar Universi- \\ ty, Al-Bayda-Libya \\ ${ }^{2}$ Department of Chemistry, Faculty of Education, Omar Al-Mukhtar University Al-Bayda-Libya
}

Received: 06 October 2020/ Accepted: 30 November 2020

Doi: https://doi.org/10.54172/mjsc.v35i3.255

\begin{abstract}
The aim of this investigation is identification and classification of Rosmarinus Officinalis essential oil components by GC-MS and prediction of their antioxidant activity. GC-MS analysis of Libyan Rosemary essential oil indicated that in total, 44 compounds were detected comprising $98.3 \%$ of compounds in the oil. The results also revealed that the oil contained some constituents with great antioxidant activity such as eugenol, $(0.04 \%)$, diethylphalate $(0.28 \%)$, myrtenol $(0.46 \%), \gamma$-Terpinene $(2.2 \%), \alpha$ - Terpenolene $(1.96 \%)$, with total percentage of $(4.94 \%)$ which was considered to be very small. However, about the half of the essential oil contained of constituents with very weak antioxidant activity. These include trans- $\beta$-caryophinen $(2.2 \%), \alpha$ - humulene $(0.34 \%), 1.8$ - cineol $(6.15 \%), 1.8$ - cineol isomer $(11.8 \%)$, linalool $(3.29 \%)$, 4-terpinol $(5.65 \%), 1-\alpha-$ terpine $(7.93 \%)$, isoborneol $(0.29 \%)$, perillaldehyde $(0.09 \%), \beta$ - citronellal $(0.03 \%), \alpha$ - pinene $(3.4 \%)$, comphen $(3.04 \%)$ and $\beta$ pinene $(4.21 \%)$, our result shows that the essential oil of Libyan Rosemary might have a weak antioxidant activity.
\end{abstract}

Keywords: Rosmarinus Officinalis, essential oils, GC-MS analysis of essential oil, antioxidants.

\section{INTRODUCTION}

Essential oil yield and chemical composition vary, considerably due to different factors, both intrinsic and extrinsic (Stahl-Biskup, 2002).Intrinsic factor includes genetic and sexual variations, plant organ (roots, leaves, stem, etc.), age and vegetative cycle stage. On the other hand, extrinsic factors and described by ecological and environmental aspects such as attitude, soil composition, climate and light, all these factors can drastically affect the chemical composition of essential oils (Stahl-Biskup, 2002). Thus, these variations are of distinct important when studying the biological activity, such as, antioxidant capacity of essential oils as the degree of activity has to be related to its chemical composition (Panizzi et al, 1993; Lahlou and Berrada, 2003; Alvarez et al., 2019).

Essential oils are commercially important especially for the pharmaceutical, cosmetic, perfume industries and medical properties, as well as in food and beverages, as flavoring agents and preservatives (Van De Braak and Leijen, 1999; Burt, 2004; Fitsiou et al., 2016).Nowadays, essential oils and their components are gaining increasing attention, because of their relatively safe status, their

*Corresponding Author: Bubaker M.B Hamed Al-Mansori science.abu@gmail.com, Department of Food Science and Technology, Faculty of Agriculture, Omar Al-Mukhtar University, Al-Bayda, Libya. 
wide acceptance by customers, and the possibility of their exploitation for potential multipurpose functional uses (Ormancey et. al., 2001). In this context, many essential oils and constituents have been studied (Ruberto and Barata, 2000; Nieto et al., 2018).For natural antioxidants with the virtue of being nontoxic has given rise to a large number of studies on the potential of the essential oils of several aromatic plants, among them, Rosemary. (Miura et al, 2002; Wang et al, 2008; Ojeda et al., 2013; Alvaraz et al., 2019).

In Libya, the Al-Jabal Al-Akhdar mountain, which is a region located in the North-East of Libya, is a rich habitat of many aromatic plants that grow wild, among them Rosemary Officinalis. These aromatic plants are used fresh or dry as spicy herbs, in many Libyan dishes, and for medical purposes (Jafri and El-Gadi, 1985). So, the aim of this study is extraction of the essential oils of Libyan Rosemary Officinalis by hydro-distillation, identification and classification of its chemical constitutes by using gas chromatography coupled to mass spectroscopy (GC-MS) and the prediction of its antioxidant activity.

\section{MATERIALS AND METHODS}

Chemical and reagent: All chemicals and reagents were highly pure which purchased from Fisher scientific (Loughborough, UK) and Sigma-Aldrich (Pool, Dorset, UK).

Plant material: Leaves of wiled plant Rosmarinus Officinalis (Rosemary) were collected during the flowering stage in April 2019) at AlJabal Al-Akhdar region in North-East of Libya, specimens of collected plant were confirmed and deposited at the Herbarium of the department of Biology, University of Tripoli, Libya. The fresh sample were frozen in sealed sample bags at $-18 \mathrm{C}^{\circ}$ till extraction.

Essential oil extraction: The classic methodology of hydro-distillation using Clevengertype apparatus was used for the isolation of the essential oil from rosemary (Rosmarinus Offic- inalis). The fresh leaves of the aromatic plants $(100 \mathrm{~g})$ were blended with water $(1500 \mathrm{ml})$ in a blender. The mixture was transferred into the hydro-distillation unit for 3-4 hours, until no more essential oil was obtained. The essential oil was separated from water, dried over anhydrous sodium sulphate and stored in sealed airtight amber glass flasks at $4 \mathrm{C}^{\mathrm{o}}$ until analyzed (Daferera et al, 2003).

\section{Identification of essential oil by gas chroma-} tography mass spectroscopy (GC-MS): Essential oil of Libyan Rosemary obtained by hydro-distillation was analyzed, and their constituents identified using GC-MS. The analysis was performed using a Shimadzu GC-MS-QP 5050 A, software class 5000, with a DBI column ( $30 \mathrm{~m} \times 0.53 \mathrm{~m}$ i.d), $1.5 \mu \mathrm{m}$ film thickness. The carrier gas was helium (flow rate $1 \mathrm{ml} / \mathrm{min}$ ). For GC-MS detection, an electron ionization mode (EI) with ionization energy $70 \mathrm{ev}$ was used. The temperature program as follows: $30 \mathrm{C}^{\circ}$ (static, for $2 \mathrm{~min}$ ) then gradually increasing (at a rate of $2 \mathrm{C}^{\circ} / \mathrm{min}$ ) up to $250 \mathrm{C}^{\mathrm{o}}$ (static for $5 \mathrm{~min}$ ). Injector temperature was $280 C^{\circ}$. Qualitative identification of the essential oil constituents was achieved using a willey 299 LIB database, and by comparing mass fragmentation patterns with those from the available published data. Quantitative estimation of the volatile constituents was determined by computerized peak are measurements using an internal normalization method. This analysis was carried out on the Regional Center for Mycology and Biotechnology, Al-Azhar university, Cairo (Egypt).

\section{RESULTS AND DISCUSSION}

The yield of the essential oil from $R$. Officinalis growing wild in Libya was $0.47 \% \pm$ $0.18 \%$, on a dry weight basis. This yield is slightly higher than those obtained from the wild Portuguese $R$. Officinalis $0.3 \%$ (Mata et al., 2007). However, it was lower than these obtained from Egyptian cultivated $R$. Officinalis $1.2 \%$ (Viud-Martos et al., 2010). Serbian R. Officinalis 1.18\% (Bozin et al ., 2007) and 
also Tunisian wild $R$. Officinalis $1.2 \%$ (Hosni et al., 2013). It is quite often that the yield of essential oil is affected by many factors, among them the species of the plant, the part of the plant and geographical and climate conditions (Sthl-Biskup, 2002).

GC-MS analysis of Libyan essential oils from R. Officinalis To rationalise the antioxidant activity of Libyan endemic plant $R$. Officinalis, it is necessary to address composition, which to the best of our knowledge has not been studied before. Compound identification was carried out using GC-MS. GC-MS analysis of the Libyan essential oil indicated that in total, 44 compounds were detected in rosemary oil comprising more than $98.3 \%$ of total compounds in the oil.The pattern of chemical contents of R. officinalis essential oils indicated that this oil were complex mixtures of several compounds. For this reason, the components were divided into six classes, namely monoterpenes hydrocarbons, oxygenated monoterpenes, sesquiterpenes hydrocarbons, oxygenated sesquiterpenes, heterogeneous hydrocarbons and oxygenated heterogeneous hydrocarbons.

\section{GC-MS analysis of Libyan R. officinalis es- sential oil}

\section{Monoterpene hydrocarbons}

The results showed that the monoterpene hydrocarbons group of the R. officinalis oil from Libya consisted of eight compounds (table 1) and represented $25.5 \%$ of the contents.

The highest content was of the $\beta$-pinene isomer and the lowest content was of $\gamma$-terpene. Although the monoterpene hydrocarbons group makes up about a quarter of the total contents of the oil, the compounds in this group were found in small concentration.In addition, this group of compounds contained some constituents that could be considered to be active as antioxidants, ranging from very weak to very strong (Ruberto and Baratta, 2000; Wang et al., 2008). $\gamma$-Terpinene and $\alpha$-terpinolene, which are known to be strong antioxidant compounds, were found in small quantities, whereas $\alpha$ pinene, camphene and $\beta$-pinene were found in measurable amounts in this group, but they are characterized by their very weak antioxidant activity.

Table:(1). Monoterpene hydrocarbons identified by GCMS analysis of Libyan R. officinalis essential oil.

\begin{tabular}{|c|c|c|c|c|c|}
\hline 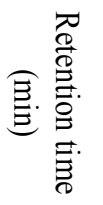 & 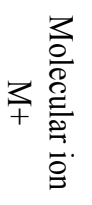 & $\begin{array}{l}\text { Base } \\
\text { Peak }\end{array}$ & $\begin{array}{l}\text { Chemical } \\
\text { compound }\end{array}$ & $\begin{array}{l}\text { Molecular } \\
\text { formula }\end{array}$ & 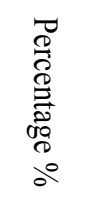 \\
\hline 13.15 & 136 & 93 & $\alpha$-pinene & $\mathrm{C} 10 \mathrm{H} 16$ & 3.4 \\
\hline 13.44 & 136 & 93 & $\begin{array}{l}\alpha \text {-pinene } \\
\text { isomer }\end{array}$ & $\mathrm{C} 10 \mathrm{H} 16$ & 3.17 \\
\hline 13.59 & 136 & 93 & camphene & $\mathrm{C} 10 \mathrm{H} 16$ & 3.04 \\
\hline 13.82 & 136 & 93 & $\begin{array}{l}\text { camphene } \\
\text { isomer }\end{array}$ & $\mathrm{C} 10 \mathrm{H} 16$ & 2.87 \\
\hline 14.28 & 136 & 93 & 1- $\beta$-pinene & C10H16 & 4.29 \\
\hline 14.47 & 136 & 93 & $\begin{array}{l}1-\beta \text {-pinene } \\
\text { isomer }\end{array}$ & $\mathrm{C} 10 \mathrm{H} 16$ & 4.61 \\
\hline 15.93 & 136 & 93 & $\gamma$-terpinene & $\mathrm{C} 10 \mathrm{H} 16$ & 2.2 \\
\hline 16.96 & 136 & 93 & $\alpha$-terpinolene & $\mathrm{C} 10 \mathrm{H} 16$ & 1.96 \\
\hline \multirow{2}{*}{\multicolumn{5}{|c|}{$\begin{array}{l}\text { Number of identified compounds } \\
\text { Percentage of the total composition }\end{array}$}} & 8 \\
\hline & & & & & $\begin{array}{c}25.54 \\
\%\end{array}$ \\
\hline
\end{tabular}

\section{Oxygenated monoterpenes}

The oxygenated monoterpenes group (table 2) was found to be the most representative group of the compounds present in the Libyan rosemary oil, representing $66.33 \%$ and containing 23 compounds.

Camphor was at the highest level (16.07\%) in rosemary oil followed by the 1,8-cineol isomer $(11.8 \%)$. On the other hand, only a very a small amount of thymol was identified $(0.2 \%)$ and there was a complete absence of carvacrol. Thymol and carvacrol are considered to be the most powerful members of this group responsible for the antioxidant activity of most essential oils (Youdim et al., 2002; Lee et al., 2005).

Furthermore, the results showed that this group (oxygenated monoterpenes) also contained a reasonable number and amount of compounds with very weak antioxidant activity. Such components are 1,8-cineol, 1,8- 
cineol isomer, 4-terpineol, 1- $\alpha$-terpineol, and very small amount of isoborneol and $\beta$ citronellal.

These results correspond well with the results obtained by Okoh et al. (2010) who found oxygenated monoterpenes and monoterpenes were the major constituents in $R$. officinalis oil. In plant essential oils, oxygenated monoterpenes and monoterpenes are mainly responsible for most of the antioxidant activities (Ruberto and Baratta, 2000).

Table:(2). Oxygenated monoterpenes identified by GCMS analysis of Libyan R. officinalis essential oil.

\begin{tabular}{|c|c|c|c|c|c|}
\hline 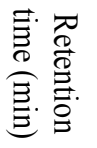 & 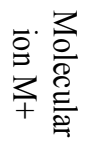 & $\begin{array}{l}\text { Base } \\
\text { Peak }\end{array}$ & $\begin{array}{l}\text { Chemical } \\
\text { compound }\end{array}$ & $\begin{array}{l}\text { Molecular } \\
\text { formula }\end{array}$ & 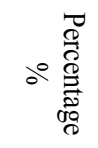 \\
\hline 15.39 & 154 & 43 & 1,8-cineole & $\mathrm{C} 10 \mathrm{H} 18 \mathrm{O}$ & 6.15 \\
\hline 16.06 & 154 & 43 & $\begin{array}{l}\text { 1,8-cineole } \\
\text { isomer }\end{array}$ & $\mathrm{C} 10 \mathrm{H} 18 \mathrm{O}$ & 11.8 \\
\hline 16.81 & 154 & 93 & linalool & $\mathrm{C} 10 \mathrm{H} 18 \mathrm{O}$ & 3.29 \\
\hline 18.04 & 152 & 108 & $\alpha$-pinene oxide & $\mathrm{C} 10 \mathrm{H} 16 \mathrm{O}$ & 0.42 \\
\hline 18.38 & 152 & 95 & camphor & $\mathrm{C} 10 \mathrm{H} 16 \mathrm{O}$ & 16.07 \\
\hline 19.39 & 152 & 95 & $\begin{array}{l}\text { comphor } \\
\text { isomer }\end{array}$ & C10H16 O & 2.01 \\
\hline 19.55 & 150 & 81 & pinocarvone & $\mathrm{C} 10 \mathrm{H} 14 \mathrm{O}$ & 4.35 \\
\hline 19.85 & 152 & 55 & $\begin{array}{l}\text { bicyelomonoter } \\
\text { pene ketone }\end{array}$ & C10H16 O & 2.11 \\
\hline 20.15 & 154 & 71 & 4-terpineol & C10H18 O & 5.65 \\
\hline 20.46 & 154 & 59 & 1- $\alpha$-terpineol & $\mathrm{C} 10 \mathrm{H} 18 \mathrm{O}$ & 7.93 \\
\hline 20.93 & 150 & 95 & $\begin{array}{c}\text { monoterpene } \\
\text { ketone }\end{array}$ & $\mathrm{C} 10 \mathrm{H} 14 \mathrm{O}$ & 3.49 \\
\hline 21.91 & 152 & 95 & $\begin{array}{c}\text { camphor } \\
\text { isomer }\end{array}$ & $\mathrm{C} 10 \mathrm{H} 16 \mathrm{O}$ & 0.22 \\
\hline 22.18 & 152 & 79 & myrtenol & $\mathrm{C} 10 \mathrm{H} 16 \mathrm{O}$ & 0.46 \\
\hline 22.60 & 152 & 69 & aldehyde & $\mathrm{C} 10 \mathrm{H} 16 \mathrm{O}$ & 0.16 \\
\hline 22.72 & 150 & 95 & $\begin{array}{l}\text { unsaturated } \\
\text { ketone }\end{array}$ & $\mathrm{C} 10 \mathrm{H} 14 \mathrm{O}$ & 0.42 \\
\hline 23.27 & 154 & 95 & isoborneol & C10H18 O & 0.29 \\
\hline 23.87 & 196 & 95 & $\begin{array}{c}\text { endobornyl } \\
\text { acetate }\end{array}$ & $\mathrm{C} 12 \mathrm{H} 2 \mathrm{O} 2$ & 0.95 \\
\hline 24.18 & 150 & 135 & thymol & $\mathrm{C} 10 \mathrm{H} 14 \mathrm{O}$ & 0.2 \\
\hline 25.07 & 154 & 41 & dihydrocarvacrol & $\mathrm{C} 10 \mathrm{H} 18 \mathrm{O}$ & 0.12 \\
\hline 25.43 & 150 & 67 & prillaldehyde & $\mathrm{C} 10 \mathrm{H} 14 \mathrm{O}$ & 0.09 \\
\hline 25.77 & 150 & 121 & aldehyde & $\mathrm{C} 10 \mathrm{H} 14 \mathrm{O}$ & 0.11 \\
\hline 26.32 & 156 & 41 & $\beta$-citronellal & $\mathrm{C} 10 \mathrm{H} 20 \mathrm{O}$ & 0.03 \\
\hline 27.83 & 164 & 43 & $\begin{array}{l}\text { monoterpene } \\
\text { oxide }\end{array}$ & $\mathrm{C} 10 \mathrm{H} 12 \mathrm{O} 2$ & 0.01 \\
\hline \multicolumn{5}{|c|}{ Number of identified compounds } & 23 \\
\hline \multicolumn{5}{|c|}{ Percentage of the total composition } & $66.33 \%$ \\
\hline
\end{tabular}

\section{Sesquiterpene hydrocarbons}

The sesquiterpene hydrocarbons group (Table 3 ) comprised of 3 compounds at a low percentage $(2.62 \%)$ of the oil constituents. This group contained two weak antioxidant compounds, trans- $\beta$-caryophyllene and humulene.

Table:(3). Sesquiterpene hydrocarbons identified by GC-MS analysis of Libyan R. officinalis essential oil.

\begin{tabular}{|c|c|c|c|c|c|}
\hline 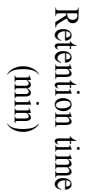 & 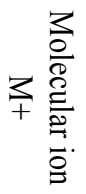 & $\begin{array}{l}\text { Base } \\
\text { Peak }\end{array}$ & $\begin{array}{l}\text { Chemical } \\
\text { compound }\end{array}$ & $\begin{array}{l}\text { Molecular } \\
\text { formula }\end{array}$ & 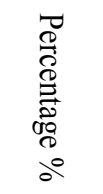 \\
\hline 32.1 & 204 & 41 & $\begin{array}{c}\text { trans- } \beta- \\
\text { caryophyllene }\end{array}$ & $\mathrm{C} 15 \mathrm{H} 24$ & 2.2 \\
\hline 33.93 & 204 & 93 & $\alpha$-humulene & $\mathrm{C} 15 \mathrm{H} 24$ & 0.34 \\
\hline 37.37 & 204 & 161 & $\alpha$-amorphene & $\mathrm{C} 15 \mathrm{H} 24$ & 0.08 \\
\hline \multicolumn{5}{|c|}{ Number of identified compounds } & 3 \\
\hline \multicolumn{5}{|c|}{ Percentage of the total composition } & $2.62 \%$ \\
\hline
\end{tabular}

\section{Oxygenated sesquiterpene and heterogeneous hydrocarbon}

The oxygenated sesquiterpene and heterogeneous hydrocarbon groups (table 4) consisted of two compounds each, spathulenol and $\delta$-cadinol, and nonane and 3,4-octadiene7-me respectively.

Table:(4). Oxygenated sesquiterpenes and heterogeneous hydrocarbons identified by GC-MS analysis of Libyan R. officinalis essential oil.

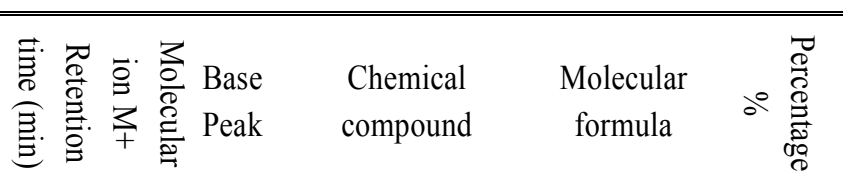

Oxygenated sesquiterpenes

$\begin{array}{llllll}41.65 & 220 & 41 & \text { spathulenol } & \mathrm{C} 15 \mathrm{H} 24 \mathrm{O} & \text { trace }\end{array}$

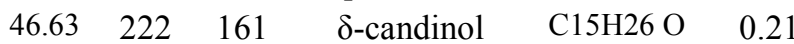

Number of identified compounds 2

Percentage of the total composition $\quad 0.21$

Heterogeneous hydrocarbons

\begin{tabular}{cccccc}
9.43 & 128 & 43 & nonane & C9 H2O & trace \\
11.87 & 124 & 67 & $\begin{array}{c}\text { 3,4-octadiene- } \\
\text { 7-me }\end{array}$ & C9 H16 & 0.02 \\
& \multicolumn{4}{c}{}
\end{tabular}

Number of identified compounds 2

Percentage of the total composition $\quad 0.02 \%$ 


\section{Oxygenated heterogeneous hydrocarbons}

The final group is the oxygenated heterogeneous hydrocarbons (table 5) consisting of 7 compounds representing 3.6\% of the oil. This group contained very important compounds with very high antioxidant activity, namely eugenol and diethyl phthalate, present in relatively small amounts but probably affecting the overall antioxidant activity of this oil.

Table:(5). Oxygenated heterogeneous hydrocarbons identified by GC-MS analysis of Libyan R. officinalis essential oil.

\begin{tabular}{|c|c|c|c|c|c|}
\hline 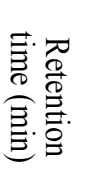 & 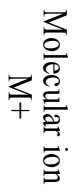 & $\begin{array}{l}\text { Base } \\
\text { Peak }\end{array}$ & $\begin{array}{l}\text { Chemical } \\
\text { compound }\end{array}$ & $\begin{array}{l}\text { Molecular } \\
\text { formula }\end{array}$ & 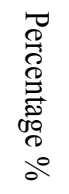 \\
\hline 5.68 & 86 & 41 & 3-me-butanol & $\mathrm{C} 5 \mathrm{H} 10 \mathrm{O}$ & 0.02 \\
\hline 14.8 & 128 & 57 & 1-octen-3-ol & $\mathrm{C} 8 \mathrm{H} 16 \mathrm{O}$ & 2.13 \\
\hline $\begin{array}{c}26.9 \\
2\end{array}$ & 164 & 164 & eugenol & $\mathrm{C} 10 \mathrm{H} 12 \mathrm{O}$ & 0.04 \\
\hline 28.53 & 178 & 178 & me eugenolate & $\mathrm{C} 11 \mathrm{H} 14 \mathrm{O} 2$ & 0.53 \\
\hline 40.05 & 222 & 149 & $\begin{array}{l}\text { diethyl } \\
\text { phthalate }\end{array}$ & $\mathrm{C} 12 \mathrm{H} 14 \mathrm{O} 2$ & 0.28 \\
\hline 68.20 & 278 & 149 & $\begin{array}{c}1,2- \\
\text { benzenedicrbo } \\
\text { xylic } \\
\text { acidbutyl-2- } \\
\text { meththyprolyl } \\
\text { ester }\end{array}$ & $\mathrm{C} 16 \mathrm{H} 22 \mathrm{O} 4$ & 0.54 \\
\hline 74.87 & 390 & 149 & $\begin{array}{c}1,2- \\
\text { benzenedicrbo } \\
\text { xylic acid bis } \\
\text { (2-ethylhexyl } \\
\text { ester) }\end{array}$ & $\mathrm{C} 24 \mathrm{H} 38 \mathrm{O} 4$ & 0.03 \\
\hline \multirow{2}{*}{\multicolumn{5}{|c|}{$\begin{array}{l}\text { Number of identified compounds } \\
\text { Percentage of the total composition }\end{array}$}} & 7 \\
\hline & & & & & $\begin{array}{c}3.51 \\
\%\end{array}$ \\
\hline
\end{tabular}

Several reports have been published (Wang et al., 2008; Viuda-Martos et al., 2010) concerning the composition of $\mathrm{R}$. officinalis essential oil; these reports have emphasized the extent of marked chemical differences among essential oils extracted from the same species. These differences in the chemical composition of $R$. officinalis oil can be attributed to the part of the plant extracted, the season of harvesting, the geographical origin and the method of extraction (Ravid and Putrisky, 1986; Mueller-Riebau et al., 1997;
Jordan et al., 2006; Bakkali et al., 2008).

The results of the GC-MS analysis in the current study were in good agreement with the results obtained by Soliman et al. (1994), who found that rosemary oil comprised 43\% compounds. However, some differences were noticed with regards to the number and quantity of some compounds in rosemary oils studied from different regions, such as the cultivated Egyptian rosemary oil, when analysed 27 compounds were identified representing $90.2 \%$ of the total oil, the major constituents were 1,8-cineole $(23.59 \%)$, camphor $(20.70 \%)$ and $\alpha$-pinene $(18.21 \%)$ (Viuda-Martos et al., 2010), and the Spanish southern $R$. officinalis oil when investigated by Tomeia et al. (1995), they found the main components to be camphor $(32.33 \%), 1,8$ cineole $(14.41 \%)$, and $\alpha$-pinene $(11.56 \%)$. The geographical location of where the plant grows can contribute to the content and quality of essential oils (Stahl-Biskup, 2002).

Earlier data pertaining to the rosemary essential oils has pointed out the difference between the Morocco/Tunisian chemotype (containing $38-55 \%$ of 1,8-cineol) and the Spanish chemotype characterized by high amount of the monoterpene hydrocarbons, $\alpha$ pinene (18-26\%), camphene (8-12\%) and 1, 8cineol (16-25\%) (Bozin et al., 2007). However, the essential oil obtained from rosemary growing wild in Libya investigated here, has a specific chemical composition, 1, 8-cineol (6.15\%), $\alpha$-pinene (3.4\%) and camphene $(3.04 \%)$ that could not be categorized in one of the two previously described chemotypes.

Finally, the differences in the number and type of the compounds in the essential oils of $\mathrm{R}$. officinalis could lead to differences in their antioxidant activities and should be taken into consideration when studying the antioxidant potential of the essential oil. In addition, the results of the essential oil composition give us, to some extent, a prediction about whether an oil has a strong or weak antioxidant activity. 
The oil under investigation contained some constituents with great antioxidant activity such as eugenol, $(0.04 \%)$, diethyl phtalate $(0.28 \%)$, myrteol $(0.46 \%), \gamma$-terpinene $(2.2 \%)$, $\alpha$-terpenolene $(1.96 \%)$, with a total percentage of $(4.94 \%)$ which was considered to be very small. However, about half of the essential oil contained constituents with a predicted very weak antioxidant activity. These included trans- $\beta$-caryophlene $\quad(2.2 \%), \quad \alpha$-humulene $(0.34 \%), 1,8$-cineol $(6.15 \%), 1,8$-cineol isomer $(11.8 \%)$, linalool $(3.29 \%)$, 4-terpineol $(5.65 \%), \quad 1-\alpha$-terpine $(7.93 \%), \quad$ isoborneol $(0.29 \%)$, prillaaldehyde $(0.09 \%), \beta$-citronellal $(0.03 \%), \alpha$-pinene $(3.4 \%)$, camphene $(3.04 \%)$ and $\beta$-pinene $(4.29 \%)$. Based on the data published by Ruberto and Baratta (2000), Youdim et al., (2002) and Wang et al. (2008) the essential oil of Libyan rosemary oil might have a weak antioxidant activity.

\section{CONCLUSION}

Rosmarinus Officinalis essential oil grow wild in Libya, is a mixture of 44 compounds, including a group of six classes namely, Monoterpenes Hydrocarbons, Oxygenated Monoterpenes, Sesquiterpenes Hydrocarbons, Oxygenated Sesquiterpenes, Heterogeneous Hydrocarbons. This oil might have a weak antioxidant activity according to its chemical constituents, where the content of the phenolic compounds which are considered being strong antioxidants too low, (Thymol, $0.2 \%$ and the absent of Carvacrol, $0.0 \%$ ). However, attention should be paid to study its extracts of Rosmarinus Officinalis plant using different solvents for extraction.

\section{ETHICS}

The authors declare no conflict of interest.

\section{REFERENCES}

Alvarez, María \& Ortega Ramirez, Luis \& Silva-Espinoza, Brenda \& Aguilar, Gustavo \& Ayala-Zavala, J. Fernando. (2019). Antimicrobial, antioxidant, and sensorial impacts of oregano and rosemary essential oils over broccoli florets. Journal of Food Processing and Preservation.

e13889.

10.1111/jfpp.13889.

Bakkali, F., Averbeck, S., Averbeck, D. and Waomar, M. (2008). Biological effects of essential oils - A review. Food and Chemical Toxicology, 46, 446-475.

Bozin, B., Mlmica-Dukic, N., Samojlik, I. and Jovin, E. (2007). Antimicrobial and antioxidant properties of rosemary and sage (Rosmarinus officinalis L. and Salvia officinalis L., lamiaceae) essential oils. Journal of Agricultural and Food Chemistry, 55, 7879-7885.

Burt, S. 2004. Essential oils: their antibacterial properties and potential applications in foods - a review. International Journal of Food Microbiology, 94, 223-253.

Daferera, D. J., Ziogas, B. N. and Polissiou, M. G. 2003. The effectiveness of plant essential oils on the growth of Botrytis cinerea, Fusarium sp and Clavibacter michiganensis subsp michiganensis. Crop Protection, 22, 39-44.

Fitsiou, Eleni \& Anestopoulos, Ioannis \& Chlichlia, Katerina \& Galanis, Alex \& Kourkoutas, Yiannis \& Panayiotidis, Mihalis \& Pappa, Aglaia. (2016). Antioxidant and Antiproliferative Properties of the Essential Oils of Satureja thymbra and Satureja parnassica and their Major Constituents. Anticancer Research.

Hosni, K., Hassen, I., Chaabane, H., Jemli, M., Dallali, S., Sebei, H. and Casabianca, H. 2013. Enzyme-assisted extraction of essential oils from thyme (Thymus capitatus L.) and rosemary (Rosmarinus officinalis L.): Impact on yield, 
chemical composition and antimicrobial activity. Industrial Crops and Products, 47, 291-299.

Jafri, S. M. H. and El-Gadi, A. 1985. Flora of Libya., Tripoli, Libya, Department of Botany, Al- Faateh Univ.

Jordan, M. J., Martinez, R. M., Goodner, K. L., Baldwin, E. A. and Sotomayor, J. A. (2006). Seasonal variation of Thymus hyemalis Lange and Spanish Thymus vulgaris L. essential oils composition. Industrial Crops and Products, 24, 253263.

Lahlou, M. and Berrada, R. (2003). Conmposition and niticidal activity of essential oils of three chemotypes of Rosmarinus officinalis L. acclimatized in Morocco. Flavour and Fragrance Journal, 18, 124-127.

Lee, S. J., Umano, K., Shibamoto, T. and Lee, K. G. (2005). Identification of volatile components in basil (Ocimum basilicum L.) and thyme leaves (Thymus vulgaris L.) and their antioxidant properties. Food Chemistry, 91, 131-137.

Mata, A. T., Proenca, C., Ferreira, A. R., Serralheiro, M. L. M., Nogueira, J. M. F. and Araujo, M. E. M. (2007). Antioxidant and antiacetylcholinesterase activities of five plants used as Portuguese food spices. Food Chemistry, 103, 778-786.

Miura, K., Kikuzaki, H. and Nakatani, N. (2002). Antioxidant activity of chemical components from sage (Salvia officinalis L.) and thyme (Thymus vulgaris L.) measured by the oil stability index method. Journal of Agricultural and Food Chemistry, 50, 1845-1851.
Mueller-Riebau, F. J., Berger, B. M., Yegen, O. and Cakir, C. (1997). Seasonal variations in the chemical compositions of essential oils of selected aromatic plants growing wild in Turkey. Journal of Agricultural and Food Chemistry, $45,4821-4825$.

Nieto, Gema \& Id, Gaspar \& Ros, Gaspar \& Castillo, Julián. (2018). medicines Antioxidant and Antimicrobial Properties of Rosemary (Rosmarinus officinalis, L.): A Review. Medicines. 5. 10.3390/medicines5030098.

Okoh, O. O., Sadimenko, A. P. and Afolayan, A. J. 2010. Comparative evaluation of the antibacterial activities of the essential oils of Rosmarinus officinalis L. obtained by hydrodistillation and solvent free microwave extraction methods. Food Chemistry, 120, 308312.

Ojeda, Adriana \& Van Baren, Catalina \& Elechosa, Miguel \& Juárez, Miguel \& Moreno, Silvia. (2013). New insights into antibacterial and antioxidant activities of rosemary essential oils and their main components. Food Control. 31.

189-195.

10.1016/j.foodcont.2012.09.022.

Ormancey, X., Sisalli, S. and Coutiere, P. 2001. Formulation of essential oils in functional perfumery Parfums, Cosmetiques, Actualites., 157, 30-40.

Panizzi, L., Flamini, G., Cioni, P. L. and Morelli, I. (1993). Composition and antimicrobial properties of essential oils of four Mediterranean Lamiaceae. Journal of Ethnopharmacology, 39, 167-170. 
Ravid, U. and Putievsky, E. (1986). Carvacrol and thymol chemotypes of East Mediterranean wild Labiatae herbs. In: Brunke, E. J. (ed.) Progress in Essential Oil Research. New York: de Gruyter, Berlin.

Ruberto, G. and Baratta, M. T. (2000). Antioxidant activity of selected essential oil components in two lipid model systems. Food Chemistry, 69, 167-174.

Stahl-Biskup, E. (2002). Essential oil chemistry of the genus Thymus - a global view. In: Stahl-Biskup, E. and Sáez, F. (eds.) The genus thymus. New York: CRC Press

Soliman, F. M., El-Kashoury, E. A., Fathy, M. M. and Gonaid, M. H. (1994). Analysis and biological activity of the essential oil of Rosmarinus officinalis L. from Egypt. Flavour and Fragrance Journal, 9, 29-33.

Tomeia, P. E., Cionib, P., Flaminib, G. and Stefanic, A. (1995). Evaluation of the Chemical Composition of the Essential Oils of Some Lamiaceae from Serrania de Ronda (Andaluçia, Spain). Journal of Essential Oil Research, 7, 279-282.

Van De Braak, S. a. a. J. and Leijten, G. C. J. J. (1999). Essential oils and oleoresins: a survey in the Netherlands and other major markets in the European Union. CBI, Centre for the Promotion of Imports from Developing Countries, pp. 116.

Villiere, A., Viau, M., Bronnec, I., Moreau, N. and Genot, C. (2005). Oxidative stability of bovine serum albumin- and sodium caseinate-stabilized emulsions depends on metal availability. Journal of Agricultural and Food Chemistry, 53, 1514-1520.

Wang, W., Wu, N., Zu, Y. G. and Fu, Y. J. (2008). Antioxidative activity of Rosmarinus officinalis L. essential oil compared to its main components. Food Chemistry, 108, 1019-1022.

Youdim, K. A., Deans, S. G. and Finlayson, H. J. (2002). The antioxidant properties of thyme (Thymus zygis L.) essential oil: an inhibitor of lipid peroxidation and a free radical scavenger. Journal of Essential Oil Research, 14, 210-215. 
تعريف وتصنيف المركبات الكيميائية لزيت نبات الإكليل النامي طبيعياً بمنطقة الجبل الأخضر والتكهن بالتأثير المضاد للاكسدة لمكوناته

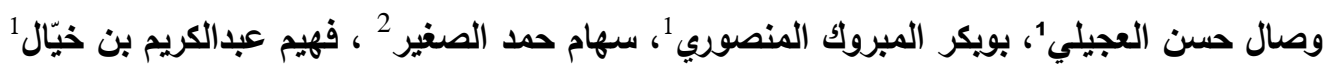

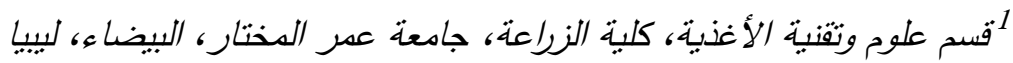

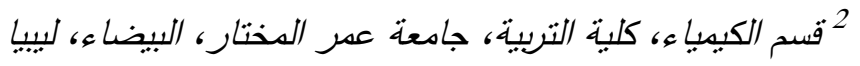

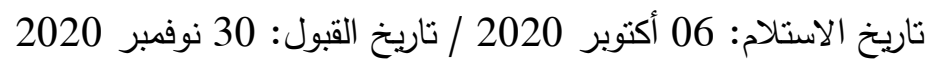 \\ https://doi.org/10.54172/mjsc.v35i3.255 :Doi
}

Rosmarinus المستخلص : يهدف هذا البحث إلى التعرف وتصنيف المكونات الكيميائية للزيت الطيار لنبات الإكليل (Officinalis

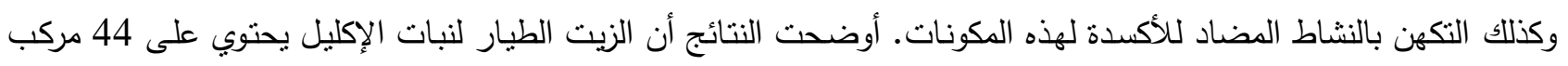

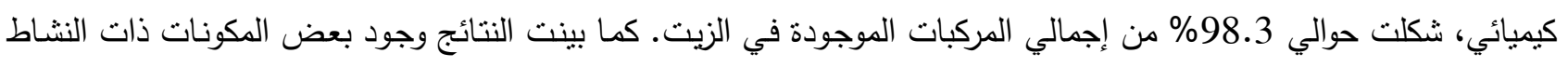

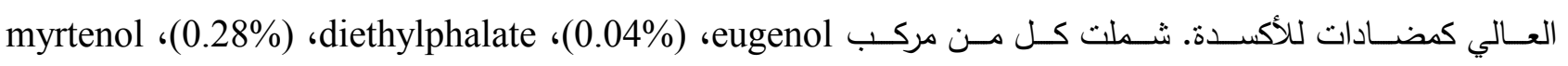
،

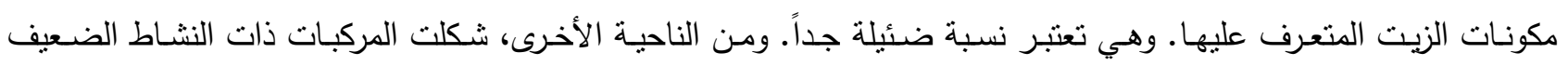

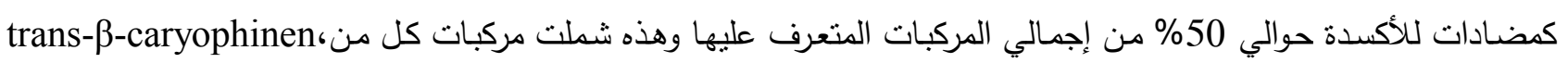

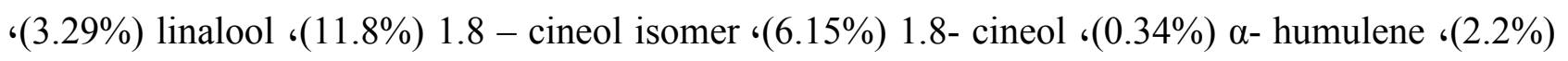
$\beta$ - citronellal ، (0.09\%) perillaldehyde، $،$ (0.29\%) isoborneol ، (7.93\%) $\alpha$-terpine ، (5.65\%) 4-terpinol

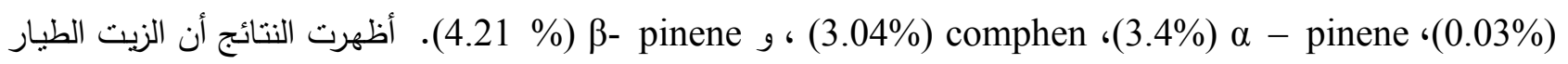
لنبات الإكليل النامي طبيعياً بمنطقة الجبل الأخضر ربما يكون له نأثير ضعيف كمضاد للأكسدة. الكلمات المفتاحية : نبات الإكليل، الزيت الطيار ، تحليل GC-MS للزيت الطيار ، مضادات الأكسدة . 